\title{
THE IMPACT OF COVID-19 PANDEMIC ON EDUCATIONAL ACTIVITIES IN OBAFEMI AWOLOWO UNIVERSITY ILE-IFE NIGERIA
}

\author{
Ayotunde David Odewale(1), Banji Marcellinus Adepoju(2), Johnson Oladimeji Edema(3) \\ (1) Department of Local Government and Development Studies, Obafemi Awolowo University Ile-Ife, Osun State, \\ Nigeria \\ (2) Department of Local Government and Development Studies, The Polythenic Ibadan, Oyo State, Nigeria \\ (3) Department of Local Government and Development Studies, Obafemi Awolowo University Ile-Ife, Osun State, \\ Nigeria \\ Correspondence Author: odewaleayo@ hotmail.com
}

\begin{abstract}
Abstrak: Tulisan ini mengkaji dampak pandemi COVID-19 terhadap kegiatan pendidikan di komunitas Universitas Obafemi Awolowo (OAU) selama dan setelah era lockdown. Pandemi berdampak pada hampir semua aspek kehidupan termasuk sektor pendidikan. Padahal, penutupan sekolah selama penguncian dimaksudkan untuk mengendalikan penyebaran virus tetapi memiliki dampak sosial ekonomi yang meluas. Data primer dan sekunder digunakan untuk penelitian ini. Kajian tersebut mengungkapkan bahwa pandemi COVID-19 menjadi faktor utama terganggunya kalender akademik hal ini sebagai akibat dunia dihadapkan pada pandemi COVID19 yang telah membebani perekonomian tak terkecuali sektor pendidikan. Oleh karena itu, penelitian menyimpulkan bahwa selama COVID-19, kegiatan pendidikan di OAU dihadapkan pada banyak tantangan seperti di perguruan tinggi lainnya di Nigeria, seperti penutupan sekolah, kehilangan sesi akademik, pembelajaran yang buruk dan ikatan sosial yang terbatas. Penelitian yang direkomendasikan antara lain; pemerintah dan manajemen lembaga harus proaktif dalam memperbaiki dampak negatif yang diidentifikasi dalam studi ini dan mengembangkan langkah-langkah untuk meningkatkan kegiatan pendidikan.
\end{abstract}

Kata kunci; COVID-19; Pandemi; Pendidikan; Pendidikan Universitas; Universitas Obafemi Awolowo

\begin{abstract}
This paper examines the impact of the COVID-19 pandemic on educational activities in the Obafemi Awolowo University (OAU) community during and after the lockdown era. The pandemic affected almost all the facets of life including the educational sector. Though, the school closure during the lockdown is intended to control the spread of the virus but had widespread socio-economic impacts. Primary and secondary data were used for the study. The study revealed that the COVID-19 pandemic is a major factor of disruption in academic calendar this was as a result of the world being faced with the COVID-19 pandemic, which has held the economy at ransom not exempting the educational sector. Hence, the study concludes that the during COVID-19, educational activities in OAU was faced with many challenges as in other higher institution in Nigeria, such as school closure, loss of academic session, poor learning and limited social ties. The study recommended among others; government and the institution`s management should be proactive in ameliorating the negative impact identified in this study and develop measure to improve educational activities.
\end{abstract}

Keywords: COVID-19; Pandemic; Education; University Education; Obafemi Awolowo University

Article Information: Submitted: 2021-12-26; Division 2022-01-20; Approved: 2022-02-03

\section{INTRODUCTION}

COVID -19 pandemic has come as a global epidemic, which affected almost all facets of life, including educational sector, though the pandemic is global in nature, but the impact is more glocalised (Odewale, Adeyemo, Osuji \& Olaleye 2021). Good governance would still be in mirage, unless we admit that our problems is not central, and cannot be solved centrally but at the source, place and by persons, where and whom is deeply felt due to the peculiarities of each locality (Odewale \& Adepoju,

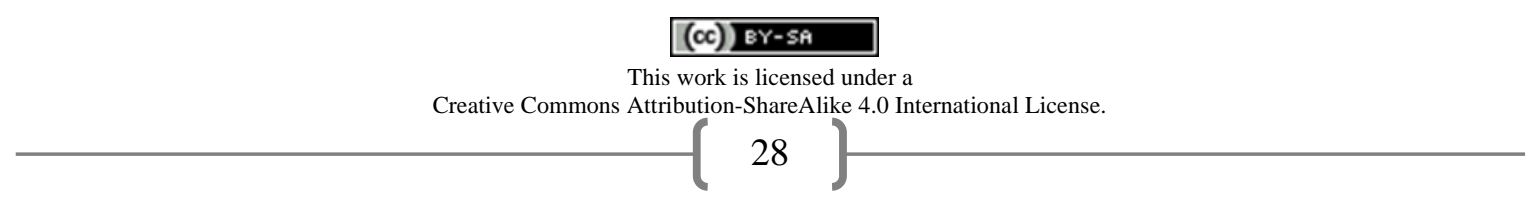


2020). This implies that the effect and impact of the pandemic are more apparent in each locality and communities with different peculiarities in experience and encounter.

The education sector is among the sectors with the devastating impact of the COVID-19 pandemic in Nigeria. In December 2019, COVID-19, a novel illness, was identified as the causal agent in reported instances of pneumonia patients admitted to hospitals in Wuhan, China (Munster, Koopmans, Doremalen, Riel, De Wit, Zhu, Zhang, Wang, Yang, Song 2020) This disease is transferred by zoonotic droplets in the air, and people can become infected by coming into close contact with the cough and sneeze of people who have symptoms from the virus (Kumar, Malviya, \& Sharma. 2020). On March 12, 2020, the World Health Organization WHO officially declared COVID-19 also known as the corona virus a pandemic (WHO 2020). Due to the severity and novelty nature of the pandemic in terms of contagiousness and infectiousness, this led to the lockdown order, physical distance, and avoidance of physical contact of individuals as much as possible especially outside the immediate family and kindred. Different nations and localities engaged in various measures to avoid physical contact, such as close down of economic activities including educational institutions, and particularly university education.

Different countries engaged in various measures to implement physical distancing, such as complete closure of the economy, including educational institutions and all other sectors which can aid the spread of the disease (Nicola, Alsafi, Sohrabi, Kerwan, Al-Jabir, Iosifidis, Agha, \& Agha, 2020; UNESCO,2020). Most educational institutions around the world were shuttered as a result of the outbreak. The school closures all over the world in April 2020 due to the pandemic affected over 1.6 billion children in 194 countries (UNESCO 2020). This is not farfetched from the Obafemi Awolowo University (OAU), Ile-Ife Nigeria. The Federal Ministry of Education in Nigeria ordered the closure of all schools, including the university education, in March 2020, and partial reopening began in October 2020.

The closure of schools compelled various school managements to come up with strategies to ensure that learning continues during the lockdown. Some Nigerian universities, particularly those that are privately owned, quickly transitioned from traditional face-to-face instruction to online learning (elearning). Though school closure is intended to control the spread of the virus within schools, prevent carriage to other vulnerable individuals, and sustain public health, these closures have had widespread socio-economic impacts. In view of the foregoing, this paper intends to look at the impact of the COVID-19 pandemic on educational activities in OAU, Ile-Ife Nigeria. The paper is divided into six parts. The first part is an introduction; the second part deals with the methodology, the third part elaborate conceptual clarifications, and the fourth part discusses the impact of the COVID-19 pandemic on educational activities in OAU, Ile-Ife Nigeria. The fifth part has a discussion of findings, while the last part presents the conclusion and recommendations.

\section{CONCEPTUAL CLARIFICATION}

\section{Covid-19 Pandemic}

Odewale, et al (2021) claim that "there are different views on the source of this pandemic called COVID-19 pandemic, some are of the opinion that the virus was intentionally or accidentally generated from Wuhan Institute of Virology, while other have objections to those views. Although the origin of COVID-19 is unknown, the scientific consensus is emerging that it is a natural, bat-to-human infection spread by Chinese traditional medicine practitioners who use bat carcasses and guano in their production". It is also pertinent to note that the phrase COVID-19 is extracted from the expression of Corona Virus Disease in the year 2019, i.e the phrase "CO" means Corona, VI means Virus, D, connote Diseases, and 19 is derived from the year 2019 (Odewale, et al 2021). The Centers for Disease Control and Prevention (CDC) also observes COVID-19 be the outbreak of a new coronavirus Severe Acute Respiratory Syndrome Coronavirus (SARS-CoV) family which comes with the respiratory illness.

Sauer, (2020) also affirms the fact that the virus has the potential to cause severe respiratory issues or death, especially in the elderly and those with underlying chronic conditions. Some infected people, on the other hand, are virus carriers with no symptoms, while others may simply have a slight illness and recover quickly. Shrikrushna, Quazi, Shubham, Suraj, Shreya, Rohit, Suraj, \& Biyani, (2020) also observe COVID-19 to be the third coronavirus to emerge in the past two decades. The first is the SARS-CoV) of 2002, the Middle East Respiratory Syndrome Coronavirus (MERS-CoV) outbreak of 
2012 is the second, while the 2019-nCoV is the third coronavirus which emerged in December 2019. Coughing and sneezing without covering one's mouth can release virus droplets into the air. Touching or shaking hands with an infected person, as well as coming into contact with a virus-infected surface or object and then touching the nose, eyes, or mouth, can spread the virus. It is believed that individuals should be motivated to make decisions that will help to avoid and control epidemics if they have enough information. Regular hand washing, using hand sanitizers, wearing face masks, respiratory etiquettes, social distancing, and self-isolation when sick was all taught to the public by government agencies and others. Though the vaccine to tackle the virus has been discovered, which make the severity of the virus to be reduced.

COVID-19 became pandemic because of its widespread, novelty, severity, and infectious nature. The epidemiology Dictionary describes a pandemic as an epidemic that occur worldwide, or over a very wide area, crossing international boundaries, and usually affecting a large number of people. In the same vein, Harris (2000) also sees a pandemic as an epidemic that affects a large number of people, spread boundaries worldwide. Qui, Rutherford, Mao, \& Chu, (2017) see a pandemic as a disease that spread over a large geographical area. The consensuses from several scholars submit that pandemic is an epidemic that spread across wide geographical areas and wear a worldwide outlook.

\section{University Education}

It is pertinent to note that the word "university" is obtained from the Latin word "Universitas" which means the "whole." or "the totality". Verger (1992) observes that the word Universitas has been in the existence since medieval times, and had been a term generally used to indicate all kinds of community or corporate such as guild, a trade, a brotherhood, and so on. Allen (1988) describes a university as an institution that has the power of awarding academic degrees and is preeminent in the field of teaching and research. More so, Alemu (2018) sees the university as a provenance of universal knowledge with highly skilled human power for the professions. The general mission of any university is to provide highly skilled human resource to all strata of the society through divers training and research. Clark (2001) opines that University education is a "multiversity" that possesses multiple purposes, and constitutes multiple people from both inside and outside the academia. A university education is a higher learning institution that brings a high level of intellectual development in science, arts, traditional professional disciplines, and promotes high-level teaching and research.

Alemu (2018) also observes that university education represents both a higher learning institution and a community of scholars or persons. University education is expected to be the pillar of any nation that would proffer solutions to societal problems through teaching and research. Otonko (2012) submits that a good university education system among its function is to help to boost the transformation of societies into knowledge societies. This it does by providing not just educated workers, but knowledgeable individuals that will be relevant to their individual life and contribute immensely to the growth of the economy in general.

\section{RESEARCH METHOD}

Primary and secondary data were used for this study. The Primary data were gathered through a questionnaire and interview method, while the secondary data were sourced through the use of content analysis of relevant documents. The questionnaires, a total of one hundred (100) copies and 8 respondents' interviewees, were outlined to recognize the impact of the COVID-19 pandemic on educational activities in OAU, Ile-Ife Nigeria. Of the total respondents, 46 (46.0\%) respondents were male, while $54(54.0 \%)$ were female. In this study, respondents were relatively drawn from two (2) concerned stakeholders, 70 (70.0\%) students and 30 (30.0\%) management staff/lecturers. These selective respondents were considered to be capable of providing comprehensive information about the impact of corona virus disease on educational activities in OAU. Due to the methodological nature of Random sampling, about 18 (18.0\%) of the respondents were from the Faculty of Administration, 7 (7\%) from Arts, 6 (6\%) Technology, 10 (10\%) Science, 5 (5\%) Environment Design and Management, 11(11\%) Social Sciences, 10(10\%) Agricultural Science, 9 (9\%) Pharmacy, 17 (17\%) Education, 5 (5\%) Law and $2(2 \%)$ Basic Medical Science. This depicts that the respondents are reliably conversant with the impact of corona virus disease on educational activities in the study area.

\section{$(c))$ EY-SA}

This work is licensed under a

Creative Commons Attribution-ShareAlike 4.0 International License. 
Table 1. The impact of covid-19 pandemic on educational activities in Obafemi Awolowo University Ile-Ife Nigeria

\begin{tabular}{|c|c|c|c|c|c|c|c|c|c|}
\hline & & $\begin{array}{c}\text { Strongly } \\
\text { Agree }\end{array}$ & Agree & Neutral & \begin{tabular}{|l|} 
Strongly \\
Disagree
\end{tabular} & Disagree & \begin{tabular}{|c|} 
No \\
Response
\end{tabular} & \multicolumn{2}{|c|}{$\begin{array}{l}\text { Descriptive } \\
\text { Statistics }\end{array}$} \\
\hline $\mathrm{S} / \mathrm{N}$ & Assertions & $f(\%)$ & $f(\%)$ & $\mathrm{f}(\%)$ & $f(\%)$ & $\mathrm{f}(\%)$ & $f(\%)$ & $\begin{array}{l}\text { Mean } \\
\text { Value }\end{array}$ & $\begin{array}{l}\text { Standard } \\
\text { Deviation }\end{array}$ \\
\hline i. & $\begin{array}{l}\text { COVID-19 is a major } \\
\text { factor in disruption in } \\
\text { academic calendar }\end{array}$ & $73(73.0)$ & $23(23.0)$ & $1(1.0)$ & $3(3.0)$ & $0(0.0)$ & $-(-)$ & 4.66 & 0.655 \\
\hline ii. & $\begin{array}{l}\text { There will be increased } \\
\text { dropout rate/ reduction in } \\
\text { enrolment during the new } \\
\text { academic session. }\end{array}$ & $22(22.0)$ & $28(28.0)$ & $26(26.0)$ & $7(7.0)$ & $17(17.0)$ & $-(-)$ & 3.31 & 1.354 \\
\hline iii. & \begin{tabular}{|lr} 
COVID-19 will lead to \\
poor & academic \\
achievement & /mass failure \\
in new academic session
\end{tabular} & $18(18.0)$ & 47 (47.0) & $16(16.0)$ & $1(1.0)$ & $14(14.0)$ & $4(4.0)$ & 3.42 & 1.401 \\
\hline iv. & $\begin{array}{l}\text { COVID-19 will lead to a } \\
\text { widening of inequality in } \\
\text { Education. }\end{array}$ & $22(22.0)$ & $50(50.0)$ & $17(17.0)$ & $4(4.0)$ & $7(7.0)$ & $-(-)$ & 3.76 & 1.065 \\
\hline v. & $\begin{array}{l}\text { COVID-19 will limit social } \\
\text { ties between lecturer, } \\
\text { learners and peers (School } \\
\text { contacts) }\end{array}$ & $28(28.0)$ & $36(36.0)$ & $22(22.0)$ & $6(6.0)$ & $5(5.0)$ & $3(3.0)$ & 3.67 & 1.256 \\
\hline $\mathrm{Vi}$ & $\begin{array}{l}\text { Before COVID-19, there is } \\
\text { Limited previous } \\
\text { experience with use of e- } \\
\text { learning. }\end{array}$ & $38(38.0)$ & $53(53.0)$ & $3(3.0)$ & $3(3.0)$ & $3(3.0)$ & $-(-)$ & 4.20 & 0.876 \\
\hline
\end{tabular}

Source: Field Survey, 2021

On the first assertion in the table, $73(73.0 \%)$ strongly agreed and $23(23.0 \%)$ agreed to the assertion that COVID-19 is a major factor in disruption in the academic calendar. $1(1.0 \%)$ of the respondents made an undecided position on this assertion; and an aggregate of $3(3.0 \%)$ of the respondents strongly disagreed on this assertion. This result showed a remarkable agreement level with the assertion. The position was confirmed by mean value and standard deviation $\bar{\chi}=4.66, \mathrm{SD}=0.655)$.

The respondents were asked to assess whether there will be an increased dropout rate/ reduction in enrolment during the new academic session. In their reactions, 22 (22.0\%) of the respondents strongly agreed and 28 (28.0\%) agreed that COVID-19 will increase dropout rate/ reduction in enrolment during the new academic session. However, 7 (7.0\%) and 17 (17\%) of the respondents strongly disagreed and disagreed respectively with this particular assertion. This implies even though COVID-19 is a major factor in disruption in the academic calendar it can not necessarily increase the rate of drop out in the next academic session, as shown by the mean value and standard deviation $\overline{(\chi}=3.31, \mathrm{SD}=1.354)$. On the other hand, it was reported that $18(18.0 \%)$ of the respondents strongly agreed that COVID-19 will lead to poor academic achievement /mass failure in a new academic session, while 47 (47.0\%) of the respondents agreed to this assertion.

However, $1(1.0 \%)$ of the respondents strongly disagreed that COVID-19 will lead to poor academic achievement /mass failure in a new academic session, while $14(14.0 \%)$ disagreed with this position with $16(16.0 \%)$ of the respondents were neutral. This implies that COVID-19 will not lead to poor academic achievement /mass failures in new academic session if all things are equal, since the mean value (3.42) are below the mid-point of 3.5. The mean value and standard deviation $\bar{X}=3.42, \mathrm{SD}$ $=1.401)$ confirmed this frequency distribution.

On the fourth item, respondents were investigated; COVID-19 will lead to a widening of inequality in Education. In their respective reactions, 22 representing $22.0 \%$ of the respondents strongly agreed that often time, there is a wide inequality gap within the zones of the country and also between the rich and the poor, while $50(50.0 \%)$ of the respondents agreed on this assertion. However, $4(4.0 \%)$ 
and $7(7.0 \%)$ of the respondents strongly disagreed and disagreed respectively. This underlines the fact that COVID-19 will lead to a widening of inequality in Education as reflected with the mean and standard deviation value $\bar{\chi}=3.76, \mathrm{SD}=1.065)$.

In addition, respondents were asked to assess whether the coming of COVID-19 will limit social ties between lecturers, learners, and peers that is, the school contacts. In their reactions, $28(28.0 \%)$ of the respondents strongly agreed and 36 (36.0\%) agreed that COVID-19 will limit social ties between lecturer, learners, and peers. However, $6(6.0 \%)$ and $5(5.0 \%)$ of the respondents strongly disagreed and disagreed respectively to this particular assertion. This implies that the social ties between lecturer, learners, and peers will be limited due to restriction on physical contact in preventing the spread of the disease, as shown by the mean value and standard deviation $\bar{\chi}=3.67, \mathrm{SD}=1.256)$.

Positively, it was reported that $38(38.0 \%)$ of the respondents strongly agreed that before COVID19, there was the limited previous experience with the use of e-learning, while $53(53.0 \%)$ of the respondents agreed to this assertion. However, $3(3.0 \%)$ of the respondents strongly disagreed that there was the limited previous experience with the use of e-learning before covid-19, while $3(3.0 \%)$ disagreed with this position and also 3 representing 3\% were undecided. This implies that COVID-19 promotes the use of e-learning in Nigeria which other western countries have been used before COVID19 , this showed a remarkable agreement as the mean value (4.20) is beyond the mid-point of 3.5. The mean value and standard deviation $\bar{X}=4.20, S D=0.876)$ confirmed this frequency distribution.

To complement the data from the questionnaire, some of the staffs and students were interviewed. Almost all the interviewees affirm their knowledge of the impact of COVID-19 pandemic on the educational activities in OAU, Ile-Ife, Nigeria. Their knowledge about the impact of COVID-19 on disruption in academic calendar of the school, the enrolment of the new students, performance of the students, social interactions, and the e-learning method were explored.

In exploring the impact of COVID-19 on the disruption on the academic calendar of the school, most of the interviewees, both students and staffs agreed to the facts that that the impact of the covid19 pandemic could be seen in the disruption of the academic calendar of OAU during the severity of the pandemic which makes the school to spurned a whole academic session of 2020-2021 from the school calendar.

Also, most of the interviewees confirm that the pandemic has a great impact on the enrolment of the students. The school has to combine 2 academic session admission for the fresh students seeking admission in the year 2021 for 2021-2022 academic sessions due to the disruption and in a way increase the enrolment of the students.

Most of the students affirmed to the fact that the method of online (e-learning) adopted in the Harmattan semester of 2019-2020 academic session has contributed to their poor academic performance because of the newness of the method of e-learning which is somehow alien to the students particularly the part one or 100level students. A 100level student in the faculty of sciences stated that: 'the e-learning method adopted during COVID-19 especially during the Harmattan semester of 2019-2020 academic session contributed to my poor performance in that semester due to some reasons which range from poor internet connectivity, appropriate devices for the e-learning from my ends, i.e laptop, and hydroid phone, interrupted power supply, and technical know-how at that time contributed to my poor performance in that semester'.

Lastly, most of the interviewees revealed that the social interaction among the lecturers, students, and peers are deterred during the COVID-19 pandemic. The use of e-learning for teaching was somehow alien to both lecturers and students before the COVID-19 pandemic. The experience was a little bit hard. The evolution of moving from the traditional way of face-to-face teaching to e-learning is like the stress of moving from analog to digital.

\section{DISCUSSION OF FINDINGS}

The impact of COVID-19 on the educational activities in OAU, Nigeria is evident as shown by this study. The study shows that COVID-19 is a major factor in the disruption of the school's academic calendar. The result from the questionnaire and interview clearly affirms the fact that COVID19 is a major factor in the disruption of the school calendar this is confirmed through the loss of a whole academic session of 2020-2021, as students were asked to resume online learning in mid-March 2021

\section{$(c))$ EY-SA}

This work is licensed under a

Creative Commons Attribution-ShareAlike 4.0 International License. 
for Harmattan 2019-2020 session. In line with respondents claim, it is said that COVID-19 will lead to poor academic achievement and mass failure in new academic session reason for this is due to idleness of students, an average unconcerned student did not take time to read during those lock-down period, some were engaged in skills acquisition such as tailoring and others. Meanwhile, the newness of the elearning method, and environmental factors that deterred the method to work perfectly contributed to the poor performance of the students especially in the 2019-2020 Harmattan semesters.

As seen in the data above, COVID-19 limit social ties between lecturer, learners, and peers (school contacts) this is as a result of the application of e-learning will limit social interaction between students and lecturer. Before COVID-19, there was a limited experience with the use of e-learning, hence, among the impact of this pandemic is the introduction of e-learning, this system has placed the institution among his contemporaries in the world is shifting to the new normal of learning aside from the old face to face form.

\section{CONCLUSION AND RECOMMENDATIONS}

The study concluded that the educational sectors in Nigeria, particularly university education were affected greatly, during the COVID-19 lock-down. The study found out that during COVID-19, educational activities in OAU were faced with many challenges as in other higher institutions in Nigeria. It is recommended therefore that educational institutions should develop contingency strategies and methods for teaching and remote learning that may be useful for emergencies such as war, crisis, and pandemics that can result in shutting down of schools, and also government and the institution`s management should be proactive in ameliorating the negative impact identified in this study and develop a measure to improve educational activities.

\section{REFERENCES}

Alemu S.K. (2018) The meaning, idea and history of university/higher education in africa: a brief literature review. FIRE: Forum for International Research in Education Vol. 4, Iss. 3, 2018, pp. 210-227

Allen, M. (1988). The Goals of Universities. USA: The Society for Research into higher Education and Open University Press

Clark, B. (2001). The Higher Education System: Academic Organization in Cross-National Perspective. Berkeley, California: University of California Press.

Harris, S. S. (2000). A Dictionary of Epidemiology, Fourth Edition.pdf.

Kumar D, Malviya R, Sharma PK (2020) Corona virus: a review of COVID-19.Eurasian J Med Oncol 4(1):8-25

Munster VJ, Koopmans M, van Doremalen N, van Riel D, de Wit E (2020) A novel coronavirus emerging in China. key questions for impact assessment. N Engl J Med 382:692-694. https://doi.org/10.1056/NEJMp2000929

Nicola, M., Alsafi, Z., Sohrabi, C., Kerwan, A., Al-Jabir, A., Iosifidis, C., Agha, M., \& Agha, $\quad$ R. (2020). The socioeconomic implications of the coronavirus pandemic (COVID-19): A review. International journal of surgery (London, England), 78, 185-193

Odewale, A. D. \& Adepoju, B.M (2020). An Appraisal of Local Government on Mandatory Functions In Southwestern Nigeria (1999-2019). American Journal of Social Sciences and Humanities, $5(2), 250-259$.

Odewale A.D, Adeyemo O.E, Osuji A.O \& Olaleye O (2020). Glocalization Nature of COVID-19 Pandemic: the Nigerian experience. Canadian Social Science. Vol. 17, No 1, 2021, pp58-72

Otonko, Jake (2012)University Education in Nigeria: History, Successes, Failures and the Way Forward.International Journal of Technology and Inclusive Education～(IJTIE) , 1(2),pg.4448 
Qiu, W., Rutherford, S., Mao,A., \& Chu ,C. (2017). The Pandemic and its Impacts. Health, Culture and Society. Vol 9-10 (2016-2017),1-11.

Sauer, L.M. (2020). What Is Coronavirus? Available online at https://www.hopkinsm edicine.org/health/conditions-and diseases/coronavirus.

Shrikrushna, S.U., Quazi, B. A., Shubham, S., Suraj, T., Shreya, W., Rohit, B., $\quad$ Suraj, S., ～\& Biyani, K. R. (2020). A Review on Corona Virus (Covid-19). World Journal of Pharmaceutical and Life Sciences. 6(4), 109-115.

UNESCO (2020). COVID-19 - A glance of national copin high-stakesexaminations and assessments. Retrieved

fromhttps://en.unesco.org/sites/default/files/unesco_review_of_high-

stakes_exams_and_assessments_during_covid-19_en.pdf

Verger, J. (1992). Patterns. In H. d.-S. (Ed.), A History of the University in Europe: Universities in the Middle Ages (pp. 35-74). Cambridge: Cambridge University Press.

World Health Organization (WHO) (2020). Retrieved from https://www.who.int/southeastasia/outbreaks-and-emergencies/novelcoronavirus-2019 